\title{
Cefmenoxime Hydrochloride
}

National Cancer Institute

\section{Source}

National Cancer Institute. Cefmenoxime Hydrochloride. NCI Thesaurus. Code C65296.

The hydrochloride salt form of cefmenoxime, a third-generation, semi-synthetic, betalactam cephalosporin antibiotic with antibacterial activity. Cefmenoxime binds to penicillinbinding proteins (PBPs), transpeptidases that are responsible for crosslinking of peptidoglycan. By preventing crosslinking of peptidoglycan, cell wall integrity is lost and cell wall synthesis is halted. 